\title{
Use of Slag from the Combustion of Solid Municipal Waste as A Partial Replacement of Cement in Mortar and Concrete
}

\author{
Monika Czop ${ }^{1, *(1)}$ and Beata Łaźniewska-Piekarczyk ${ }^{2}$ \\ 1 Department of Technologies and Installations for Waste Management, Faculty of Energy and Environmental \\ Engineering, The Silesian University of Technology, Konarskiego 18, 44-100 Gliwice, Poland \\ 2 Department of Building Engineering and Building Physics, Faculty of Civil Engineering, The Silesian \\ University of Technology, Akademicka 5, 44-100 Gliwice, Poland; beata.lazniewska@polsl.pl \\ * Correspondence: monika.czop@polsl.pl; Tel.: +483-2237-2104
}

Received: 10 March 2020; Accepted: 30 March 2020; Published: 31 March 2020

check for updates

\begin{abstract}
In Europe, the use of wastes in the cement and construction industry follows the assumptions of sustainability and the idea of circular economy. At present, it is observed that cement plants introduce wastes to the cement in the form of so-called mineral additives. The most often used mineral additives are: fly ash with silica fume, granulated blast furnace slag and silica fume. The use of mineral additives in the cement is related to the fact that the use of the most expensive component of cement-Portland cement clinker-is limited. The purpose of the article is a preliminary evaluation of the suitability of slag from the municipal solid waste incineration plant for its use as a replacement of cement. In this article, slag from the municipal solid waste incineration (MSWI) replaces cement in the quantity of $30 \%$, and presents the content of oxides and elements of slag from the MSWI. The obtained results are compared to the requirements that the crushed and granulated blast furnace slag need to meet to be suitable for use as an additive of type II to the concrete. The conducted analyses confirmed that the tested slag meets the requirements for the granulated blast furnace slag as an additive to the concrete in the following parameters: $\mathrm{CaO} \leq 18.0 \%, \mathrm{SO} 3 \leq 2.5 \%$ and $\mathrm{Cl} \leq$ $0.1 \%$. At the same time, mechanical features were tested of the designed mortars which consisted of a mixture of Portland cement (CEM I) with $30 \%$ of slag admixture. The designed mortar after 28 days of maturing reached a compressive strength of $32.0 \mathrm{MPa}$, and bending strength of $4.0 \mathrm{MPa}$. When compared to the milled granulated blast furnace slag (GBFS), the obtained values are slightly lower. Furthermore, the hardened mortars were subject to a leachability test to check the impact on the environment. Test results showed that the aqueous extracts from mixtures with $30 \%$ of slag admixtures slightly exceed the limits and do not pose a sufficiant threat to the environment as to eliminate the MSWI slag from economical use.
\end{abstract}

Keywords: municipal solid waste minimization; incineration; circular economy; slag; addition; cement; mortar; concrete

\section{Introduction}

In the past couple of years, we have observed a constant increase of the produced municipal waste. In 2018, 2.5 billion $\mathrm{Mg}$ of waste was generated in the EU countries. Municipal waste accounts for about 10\% of their total stream. According to the data provided by Eurostat [1], in 2019, each inhabitant of Europe produced $489 \mathrm{~kg}$ of municipal wastes. Municipal wastes are considered as a global problem because they are very much visible and have very complex characteristics. Their amount and morphological content depend strongly on the civilization development, quality of life and society's wealth. The form and weight of the produced municipal wastes are also strongly 
affected by the population density, type of land development (single houses, multi-family buildings), touristic attractiveness, public utility buildings and type, size and amount of commercial buildings [2].

The increasing stream of municipal wastes becomes one of the most important challenges in the European Union in respect of the environment protection and legal requirement. The waste directive 2008/98/EC explicitly specifies the order of importance in waste management: reduce, reuse, recycle, recover and dispose of [3]. The strategic goal of the EU is a complete elimination of the disposal of municipal wastes. The municipal wastes, first of all, need to be recycled (material, chemical and organic recycling) or, as an alternative, combusted with the purpose of the energy recovery. Energetic use of waste is a good solution for poor quality fractions. These wastes, due to their high heterogeneity and amount of contaminants, cannot be directed to material, raw material or chemical recycling. Until now, they "ended their life cycle" at the landfill. This solution is a waste of resources. Energetic use brings great ecological benefits, which are associated with reducing the amount of waste deposited. In addition to ecology, economics is important. Economic benefits are associated with saving exhaustible resources of fossil fuels.

One of the methods of solid waste management is thermal degradation in a municipal solid waste incineration plant (MSWI). It needs to be noted that the wastes that undergo thermal processing are the wastes which, after selective collecting, for many reasons are not suitable for recycling (i.e., low quality, high contamination, non-homogenous stream) but that have high energy value. The thermal degradation of wastes is based on the possibility to use the wastes to obtain heat or electrical energy. Furthermore, it reduced up to $90 \%$ the volume of the stream of wastes. As a result of the thermal processing, secondary solid waste is produced $[2,4]$. Solid secondary wastes include fly ash solid waste from the purification of the exhaust fumes and bottom slag. Particular attention shall be paid to the bottom slag, which following preliminary valorization may constitute valuable alternative aggregate for the use of the construction industry [5].

Correctly conducted process of combustion/co-combustion of wastes should guarantee an appropriate level of transformation of solid products of combustion, expressed by maximum content of non-oxygenated organic compounds in the following measurements [6]:

- The total content of organic carbon in slags and furnace ash should not exceed $3 \%$.

- The percentage of combustible elements in slags and furnace ash should be less than $5 \%$.

The use of the secondary products in the cement and construction industry is compliant with the idea of the circular economy (Figure 1) [5]. Replacing clinkers with active mineral additives starts to play a more and more important role in the production technology of the types of cement. Worldwide, in the production of cement, this process is based both on economic and ecological values.

Poland does not have any experience in the use of this sort of waste in the construction industry, because in previous years (up to 2016) there were not any significant amounts of these wastes. We only base on Poland's experience, within an academic register of foreign plants which cannot be transferred to the Polish market. It needs to be noted that the quality of the input stream to the system reflects the output stream. At present, Poland is at the stage of constructing a modern waste management system with the elements of the circular economy. Therefore, we need to conduct tests and broaden our knowledge on the changeability of the input stream in the course of the time depending on the thermal processing and evaluate the impact of the thermal processing on the composition of the secondary materials (slag, fly ash, waste from the purification of the exhaust fumes). Such information will be helpful, if not indispensable, when choosing the best criteria for the safe use of the secondary materials in the construction industry, avoiding any negative impact on the environment. A potential threat when using secondary waste from the thermal degradation of municipal waste for the production of mortar and concrete is the migration of heavy metals to the soil and water environment. High levels of chloride salts and sulfates may prove to be environmentally problematic. The negative effect of salt migration into the environment may be the extinction of living organisms, which can lead to a reduction in species biodiversity [7]. The high salt content can inhibit plant growth, reduce their 
size and the number of leaves and roots. As a result of salt accumulation in soil, nutrients such as phosphorus, calcium and potassium may be leached.

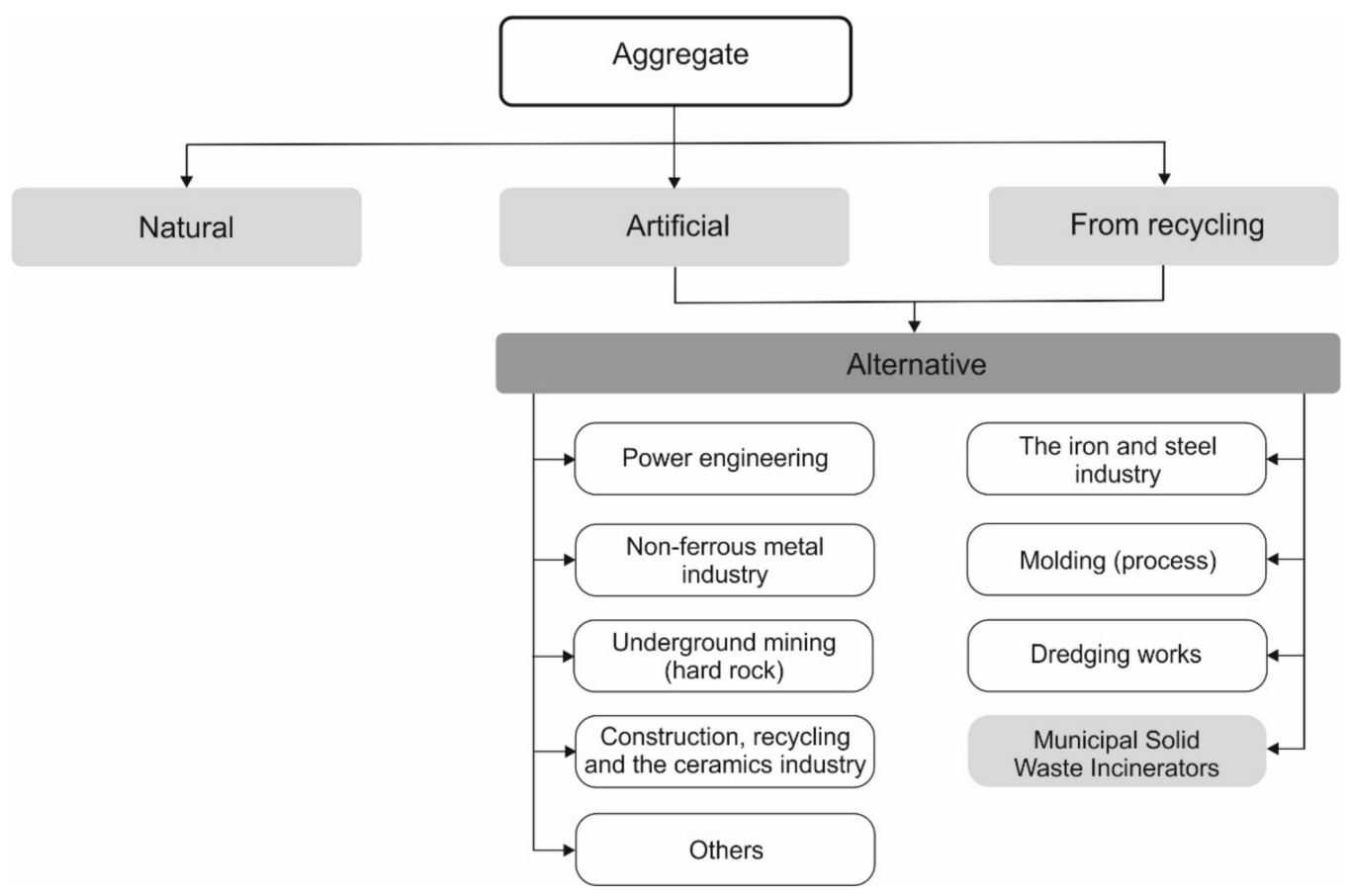

Figure 1. The direction of using anthropogenic raw materials in the circular economy (author: Czop, based on [5]).

The approach presented in this article is ecologically friendly because it aims at the best and safe use of the slag from the MSWI by replacing part of the cement with slag of similar parameters. In this way, the emission of the greenhouse gases in cement plants, mainly emission of $\mathrm{CO}_{2}$ can be limited. It needs to be noted that with the production of $1 \mathrm{Mg}$ of cement $1 \mathrm{Mg}$ of $\mathrm{CO}_{2}$ is generated and the participation of the cement industry in the global $\mathrm{CO}_{2}$ emission caused by human being amounts to $5 \%-8 \%$ [8].

\section{The Analyzed Municipal Solid Waste Incineration Plant}

The thermal degradation installation processes $210 \mathrm{Mg}$ of waste annually. It has two combustion lines that work independently of each other. The boiler has a temperature of $1000{ }^{\circ} \mathrm{C}$, and cleaned exhaust gases are discharged up to a $50 \mathrm{~m}$ chimney. The final effect of the process is electricity $(128,000 \mathrm{MWh} / \mathrm{year})$ and thermal energy (300,000 GJ/year). The energy produced is used for the needs of the city [9].

The installation accepts waste with an average calorific value of $7.5 \mathrm{GJ} / \mathrm{Mg}$. These include, among others: residua waste (20 03 01), bulky waste (20 03 07), in addition to waste constituting combustible waste (refuse-derived fuel, 19 12 10) [10].

Residual municipal waste collected in the city is transported by cars to the installation. The vehicle enters the scale. The mass of collected waste is measured and passes through the radiosensitive gate. The vehicle is directed to the delivery hall. The hall has negative pressure to prevent unpleasant odours from spreading. The waste goes to the bunker, in which the gripper mixtures the waste to avoid self-ignition and to unify the mass in the event of installation shutdown. An independent deodorizing system is installed in the bunker. Pre-prepared waste is ready for thermal treatment with energy recovery. The waste is directed to the hopper using a gripper. Then the feeder is directed to the grate, where they are thermally transformed. The waste gases generated in the process are cleaned [9]. The flue gas cleaning system in the installation consists of the following elements: bag filters, NOx reduction system, semi-dry reactor, draft fan, chimney and emission measurement station, turbine-generator, air-cooled condenser and heat exchanger, which are installed for energy recovery. 
Secondary wastes from the process are: slag (19 0111$)$, fly ash $\left(190113^{*}\right)$ and solid waste from flue gas treatment $\left(190107^{*}\right)$ [9]. A scheme depicting the process of solid waste management is presented in Figure 2.

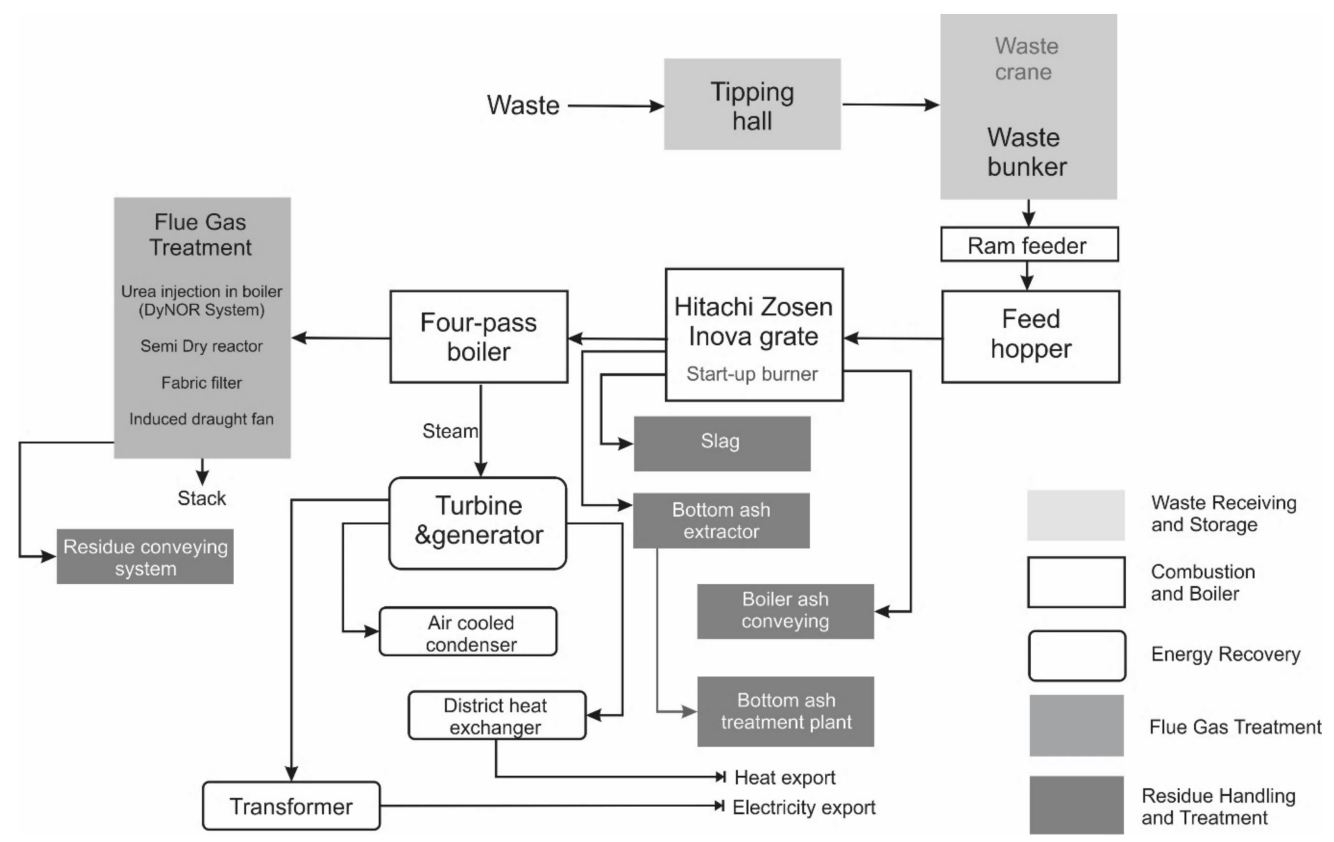

Figure 2. Simplified scheme of an analyzed municipal solid waste (MSW) incinerator (author: M. Czop based on [2]).

\section{MSWI Slag as A Potential Component of Cement for Mortar and Concrete}

Analysis of the mechanical properties indicates that slag (S) from the MSWI plant is a component that fills microstructure of mortars without pozzolan properties, unlike granulated blast furnace slag (GBFS). When preparing mortars based on MSWI slag, particularly undesirable are reactions between cement and aluminum and zinc found in the wastes. Concrete may swell because of the salts such as sulfurs $\left(\mathrm{SO}_{4}\right)$, which can be found, for example, in the soil, in the direct contact with the concrete. It leads to a chemical reaction with aluminum contained in the cement generating an expansive substance. These phenomena may lead to inciting internal tensile forces and consequently to the occurrence of cracks, in case of excessive concrete resistance [11-13]. The reasons and the process of the above mentioned chemical reactions are described in details in the publications. It is known that these reactions cause swelling and even cracking of concrete [12-14].

Furthermore, non-homogeneity of the slag from the MSWI plant and significant content of harmful components (unburnt coal and sulfur compounds) are the main reasons for low resistance of the concrete and limit the way of its use. Depending on the composition, concrete strength reaches 2-10 MPa. Slag from MSWI plant shall not be used for the production of reinforced concretes and concretes exposed to permanent humidity over $75 \%$. When the amount of the substance mentioned above is high, mortar/concrete may tend to change volume (shrinkage, swelling) under the wet conditions. The reason is usually the content of unburnt coal. Water absorption of the slag-concrete, depending on the type of slag and composition of concrete, equals $15 \%-25 \%$. Frost resistance is generally satisfactory, under the condition that the slag used does not contain a large amount of unburnt coal $(C<5 \%)$, and the concrete resistance is not lower than $5 \mathrm{MPa}[13,14]$.

Concrete with the additive of slag from the MSWI is used in the building industry almost exclusively for the production of various types of hollow wall bricks and less often for the construction of monolith walls in the first two floors in individually constructed houses. Due to the unfavorable 
results of experiments, it is no longer used in the monolith wall, and only small wall elements are made of it.

To be suitable for use in a responsible way, the slag from the MSWI plant needs to be seasoned and processed. Depending on the original composition and eventual destination, processing of slag may assume various forms (seasons, rinsing, washing, exposing to sodium hydroxide, removal of heavy metals, vitrification to assure the expected quality of the concrete) [11]. One of the most frequent problems will be the necessity to reduce aluminum and the amount of glass contained in the slag and control, among other elements such as the amount of unburnt coal, chloride, zinc and sulfur. Additionally, the possibility that potentially hazardous substances get through to the environment needs to be limited. [14,15].

There is a lack of national requirements for the slag of the MSWI as the addition to the cement. For the needs of this article, the discussions were based on the requirements for the milled granulated blast furnace slag (GBFS), used as additive of type II to concrete [16]. The standard requirements for GBFS are presented in Table 1.

Table 1. The requirements for the milled granulated blast furnace slag [16].

\begin{tabular}{cccc}
\hline Parameter & Symbol & Unit & $\begin{array}{c}\text { Standard Requirement } \\
\text { [16] }\end{array}$ \\
\hline Specific surface area & - & $\mathrm{cm}^{2} / \mathrm{g}$ & $\geq 2750.0$ \\
Magnesium oxide & $\mathrm{MgO}$ & & 18.0 \\
Sulfide & $\mathrm{S}^{2-}$ & & $\leq 2.0$ \\
Vitreous phase & - & $\%$ & $\geq 67.0$ \\
Sulfates & $\mathrm{SO}_{3}$ & & $\leq 2.5$ \\
Loss on ignition & $\mathrm{LOI}$ & & $\leq 3.0$ \\
Chloride & $\mathrm{Cl}^{-}$ & & $\leq 1.0$ \\
Moisture & $\mathrm{M}_{\mathrm{T}}$ & & $\leq .1$ \\
\hline
\end{tabular}

The purpose of the article is a preliminary evaluation of the physical, chemical and mechanical properties of the slag from the municipal solid waste incineration plant used as an addition to the mortar and in future in concrete. The volume of the mortar in concrete is about $55 \%-60 \%$, which allows the assessment of the concrete based on the examination of the properties of the mortar (they do not take into account the influence of the coarse aggregate compact zone).

\section{Materials and Methods}

\subsection{Materials}

For the tests, Portland cement was used-CEM I 42.5R (further on marked as CEM I) following the requirements of PN-EN 197-1:2002 [17]. The main component of the Portland cement CEM I (Figure 3a) is Portland cement clinker ( $\geq 95 \%$ ). The material was a product of sintering of the mixture of raw materials. Its main chemical components are four oxides: calcium oxide, silicon oxide, aluminum oxide and iron oxide.

The second material used for tests was slag (Figure 3b) which was generated as a side effect of the thermal processing of municipal wastes. Within a year in the MSWI plant, which was the time-span of consideration, $55909 \mathrm{Mg}$ of coarse and fine slag was produced [9].

At the beginning of the research, a chemical analysis of the tested materials was carried out. Oxides content and concentration of heavy metals in cement and slag from the MSWI were investigated. The obtained results are presented in Tables 2-4. The tested materials have similar oxides content. The basis phase component of slag from the MSWI is $\mathrm{SiO}_{2}$. The high content of silica $\left(\mathrm{SiO}_{2}>50 \%\right)$ may be reflected in respective high pozzolana activity. Content of $\mathrm{CaO}$ meets the requirements for the crushed, granulated blast furnace slags. $(\mathrm{CaO} \leq 18 \%)$. 


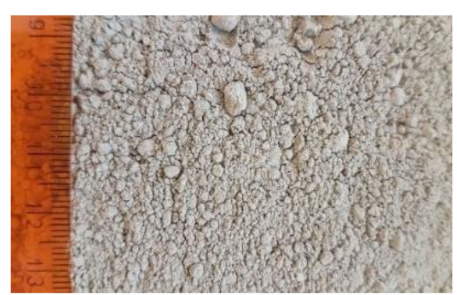

a)

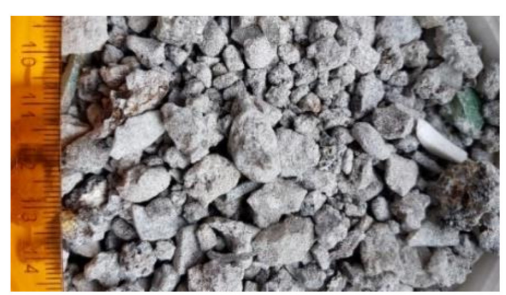

b)

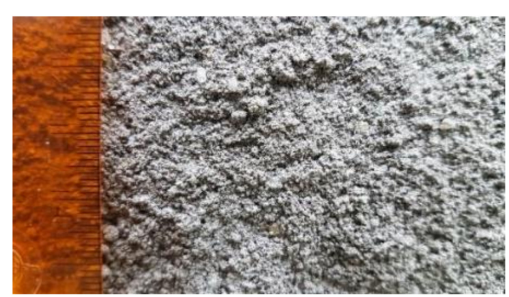

c)

Figure 3. Analyzed materials: a) cement (CEM I), b) municipal solid waste incineration (MSWI) raw slag and c) ground slag (authors' photo).

Table 2. Content of oxides (\%) in the tested materials.

\begin{tabular}{cccc}
\hline Properties & Symbol & CEM I & Slag-MSWI \\
\hline Silicon dioxide & $\mathrm{SiO}_{2}$ & 14.00 & 57.90 \\
Iron(III) oxide & $\mathrm{Fe}_{2} \mathrm{O}_{3}$ & 3.03 & 4.97 \\
Aluminum oxide & $\mathrm{Al}_{2} \mathrm{O}_{3}$ & 7.47 & 10.80 \\
Manganese(II,III) oxide & $\mathrm{Mn}_{3} \mathrm{O}_{4}$ & 0.12 & 0.12 \\
Titanium dioxide & $\mathrm{TiO}_{2}$ & 1.09 & 0.50 \\
Calcium oxide & $\mathrm{CaO}$ & 51.20 & 12.50 \\
Magnesium oxide & $\mathrm{MgO}$ & 1.61 & 1.73 \\
Sulfur trioxide & $\mathrm{SO}_{3}$ & 9.59 & 0.74 \\
Phosphorus pentoxide & $\mathrm{P}_{2} \mathrm{O}_{5}$ & 1.01 & 0.74 \\
Sodium oxide & $\mathrm{Na}_{2} \mathrm{O}$ & 3.05 & 6.61 \\
Potassium oxide & $\mathrm{K}_{2} \mathrm{O}$ & 3.77 & 0.95 \\
Barium oxide & $\mathrm{BaO}$ & 0.14 & 0.14 \\
Strontium oxide & $\mathrm{SrO}$ & 0.05 & 0.06 \\
\hline
\end{tabular}

Table 3. Composition mix of mortars, expressed in gram.

\begin{tabular}{ccccc}
\hline Type of Waste & Symbol of Mortar & CEM I, g & Water, g & Standard Sand, g [17] \\
\hline $\begin{array}{c}\text { Reference sample from } \\
\text { Portland cement 42.5 R } \\
\begin{array}{c}\text { Cement + 30\% slag } \\
\text { Cement + 30\% }\end{array}\end{array}$ CEM I & 450 & 225 & 1350 \\
$\begin{array}{c}\text { Granulated Blast } \\
\text { Furnace Slag }\end{array}$ & CEM I + 30\% GBFS & 315 & 135 & 1350 \\
\hline
\end{tabular}

Table 4. Heavy metal concentration, expressed in $\mathrm{mg} / \mathrm{kg}$.

\begin{tabular}{cccc}
\hline Properties & Symbol & CEM I & Slag-MSWI \\
\hline Zinc & $\mathrm{Zn}$ & 617.00 & 1621.00 \\
Copper & $\mathrm{Cu}$ & 94.70 & 1918.00 \\
Lead & $\mathrm{Pb}$ & 87.80 & 687.00 \\
Nickel & $\mathrm{Ni}$ & 20.80 & 81.00 \\
Chrome & $\mathrm{Cr}$ & 113.00 & 342.00 \\
Cadmium & $\mathrm{Cd}$ & 3.30 & 3.35 \\
Arsenic & $\mathrm{As}$ & 6.11 & 16.50 \\
Vanadium & $\mathrm{V}$ & 34.40 & 30.00 \\
Thallium & $\mathrm{Tl}$ & $<1.00$ & $<1.00$ \\
Mercury & $\mathrm{Hg}$ & 0.07 & 0.24 \\
\hline
\end{tabular}

The composition of the tested mortars is presented in Table 4. Mortar containing CEM I 42.5 was prepared according to requirements of EN-196-1 [17]. Portland cement CEM I 42.5R (marked as CEM I) was used in case of reference mortar. The binder made with Portland cement CEM I 42.5R with 30\% of slag from the incineration plant (hereinafter marked as CEM I + 30\% S-MSWI) was used to investigate the influence of slag (MSWI) to properties of mortars. The binder made with the Portland cement CEM 
I $42.5 \mathrm{R}$ with $30 \%$ the addition of crushed blast furnace gravel (hereinafter marked as CEM I $+30 \%$ GBFS) was used as reference slag to MSWI slag.

The mortars were prepared following the procedure described in standard EN 197-1:2011 [18] with the use of automatic vortex mixer (Table 3).

Conducted tests of heavy metals content in cement CEM I confirmed a high level of most of the trace elements, i.e., $\mathrm{Zn}>\mathrm{Cr}>\mathrm{Cu}>\mathrm{Pb}>\mathrm{V}>\mathrm{Ni}>\mathrm{As}>\mathrm{Cd}>\mathrm{Tl}>\mathrm{Hg}$ (Table 4). Higher content of heavy metals in CEM I is related to the increased content of waste fuels in the production of clinker. According to the author of publication $[19,20]$, at present, it is difficult to determine the source of heavy metals in the cement. However, the content of heavy metals in the dry mass of tested slag was high. The raw of elements was as follows: $\mathrm{Cu}>\mathrm{Zn}>\mathrm{Pb}>\mathrm{Cr}>\mathrm{Ni}>\mathrm{V}>\mathrm{As}>\mathrm{Cd}>\mathrm{Tl}>\mathrm{Hg}$.

\subsection{Methods}

The testing procedure is planned and realized in such a way as to determine the characteristics of slag (physical and chemical) which are important in the light of its use a partial replacement of cement. Impact on the environment was also taken into consideration.

Moisture content in the tested sample of slag was determined in compliance with the standard EN 15934: 2013 [21] and bulk density was determined following standard EN 1097-3:2000 [22].

The slag sample was crushed in a ball mill and underwent physical and chemical analyses. The specific surface was determined according to standard EN 196-6:2019-01 [23] and loss at ignition following standards: EN 15935:2013-02 [24] and EN 196-2:2013-11 [25]. Slag sample was also tested for the content of the following elements: carbon (C)-EN 15407:2011 [26], organic carbon (TOC)-EN-Z-15011-3:2001 [27], sulfur (S)-EN-ISO 334:1997 [28] and chloride (Cl)-EN-ISO 587:2000 [29].

The concentration of sodium, calcium, potassium, lithium and barium was determined with the flame photometry method—in compliance with the standard EN-ISO 9964-3:1994 [30].

To determine the concentration of heavy metals in the dry mass of samples, an inductively coupled plasma mass spectrometer from Perkin Elmer Company was used. It allows defining elements activated in argon plasma [31].

The aqueous extract from the slag was prepared in compliance with the standard PN-EN 12457-2:2006 [32]. From the waste weighing $2 \mathrm{~kg}$, a representative laboratory sample was prepared. Tested wastes were sieved through sieves of $2 \mathrm{~mm}$ mesh size. From such a prepared sample aqueous extract was made. The relations of liquid to the solid phase was $\mathrm{L} / \mathrm{S}=10 \mathrm{dm}^{3} / \mathrm{kg}$ (basic test). The elution liquid was distilled water of $\mathrm{pH} 7.1$ [33] and electrical conductivity of $61.18 \mu \mathrm{S} / \mathrm{cm}$ [34]. Subsequently, the extract was mixed in the vortex mixer for $24 \mathrm{~h}$, before filtering the suspension. Aqueous extracts for mortar samples were prepared in the same way. The mortar specimens were solid and crushed to the grain size of $<10 \mathrm{~mm}$.

Analysis of the aqueous extracts from slag and cement mortar included several determinations. Content of organic carbon was determined using analyzer Vario TOC Cube from the company Elementar [35]. The $\mathrm{pH}$ of the solutions [33] and conductivity [34] was identified with the use of Elmetron CPC-501 apparatus. The concentration of chlorides was determined with the Mohr method with the use of silver nitrate (v) as titration reagent and potassium dichromate (VI) as an index (PN-ISO 9297:1994 [36]). The content of sulphates (VI) $\left(\mathrm{SO}_{4}{ }^{2-}\right)$ was tested with gravitation method with barium chloride, according to the standard PN-ISO 9280:2002 [37].

The concentration of potassium, calcium, lithium and barium in aqueous extracts of ashes and mortar was determined with the flame photometry method-in compliance with standard EN-ISO 9964-3:1994 [30]. For the evaluation of the content of heavy metals in the aqueous extract an inductively coupled plasma mass spectrometer was used from Perkin Elmer company, which allows determining elements arising in argon plasma [31].

Binding time of the slurry of CEM I 42.5R with the $30 \%$ slag was tested in the automatic device of Vicata according to the procedure specified in EN 196-3 [38]. 
Consistency of the mortars was determined using a flow table method as specified in EN 1015-3 [39]. The mortar was placed on a flow table in the truncated mould in two layers. After that, the flow table was mechanically raised by $10 \mathrm{~mm}$ and dropped at a rate of once per second for about $15 \mathrm{~s}$. The flow diameter of the mortar was measured in orthogonal directions to determine the consistency of mixtures.

Further, the air content was measured as per EN 1015-7:1999 [39] by pouring and tamping the mortar in the air entrainment meter and applying an air pressure that forced the application of water into the mortar and relocating the air within the pores.

Determination of the volume changes according to EN 196-3 [40] is conducted with the use of standard slurry (Table 3), which is placed in Le Chatelier's device with measurement wires. Once the ring is filled up with the cement paste, it is preserved in the temperature of $20^{\circ} \mathrm{C}$ with the relative humidity of $98 \%$ for $24 \mathrm{~h}$. After $24 \mathrm{~h}$, the distance X between the wires should be measured. After that, The cement paste leaven in le Chatelier ring is then boiled in water for $3 \mathrm{~h}$. In the next step of research, the ring is cooled to the temperature of $20{ }^{\circ} \mathrm{C}$, and the distance $\mathrm{Y}$ between the wires is measured. The difference between $\mathrm{Y}$ and $\mathrm{X}$ is a measure of volume consistency. It meets the standard if it doesn't exceed $10 \mathrm{~mm}$ [40].

Mass absorbability $\left(\mathrm{n}_{\mathrm{w}}\right)$ of mortars is calculated on the basis of the following Equation (1):

$$
n_{w}=\frac{\left(m_{s}-m_{d}\right)}{m_{d}} * 100 \%
$$

where:

$\mathrm{m}_{\mathrm{s}}$-a mass of the water-saturated sample, $\mathrm{g}$.

$\mathrm{m}_{\mathrm{d}}-\mathrm{a}$ mass of the dry sample, $\mathrm{g}$.

Tensile and compressive strength after 2 and 28 days of the mortar maturation was performed in compliance with standard EN 196-1 [17]. The samples were removed from forms after $48 \mathrm{~h}$ and kept in water until the analysis. The tests were executed on maturing samples in the temperature of $20 \pm 2{ }^{\circ} \mathrm{C}$. Furthermore, it was evaluated if the beams of mortars changed their volume to confirm or eliminate the swelling effect.

\section{Results and Discussion}

\subsection{Physical and Chemical Properties of MSWI Slag}

Table 5 presents the basic technical properties of tested slag from MSWI plant. The total moisture content of the slag amounts to $4.5 \%$. This value is higher than recommended in the standard $(\leq 1.0 \%)$. Higher moisture content may affect puzzolana activity. Moisture content in the slag may be lowered by extending the period of seasoning.

Table 5. Basic technical properties of tested slag.

\begin{tabular}{cccc}
\hline Properties & Symbol & Unit & Slag \\
\hline Moisture & $\mathrm{M}$ & $\%$ & 4.48 \\
Bulk density & $\rho_{\mathrm{b}}$ & $\mathrm{kg} / \mathrm{m}^{3}$ & 1700.0 \\
Specific surface area & $\mathrm{S}$ & $\mathrm{cm}^{2} / \mathrm{g}$ & 3200.0 \\
Total carbon & $\mathrm{C}$ & $\%$ & 2.26 \\
Total organic carbon & $\mathrm{TOC}$ & $\%$ & 0.52 \\
Sulfur & $\mathrm{S}$ & $\%$ & 0.78 \\
Chlorine & $\mathrm{Cl}$ & $\%$ & 0.12 \\
\hline
\end{tabular}

Bulk density of tested slag reached $1700 \mathrm{~kg} / \mathrm{m}^{3}$, which is higher than the bulk density of the tested cement $\left(900-1500 \mathrm{~kg} / \mathrm{m}^{3}\right)$. 
Among physical properties which GBFS needs to meet to be acceptable for use as the addition of type II to the concrete, size of specific surface area was defined.

The size of the specific surface area of the tested slag was $3200.0 \mathrm{~cm}^{2} / \mathrm{g}$, so the slag meets the requirements for GBFS according to the standard.

The undesirable components of the possible mineral additive include an excessive amount of compounds of sulfur, chloride and unburnt coal. The high content of the unburnt coal (C > $\%$ ) may increase water demand and decrease frost resistance of mortars or concretes made with these mortars. The concentration of chloride, sulfur and organic coal in the tested slag was below $1.0 \%$. Low content of the above elements $(\mathrm{S}, \mathrm{TOC}, \mathrm{Cl})$ was reflected in a very low leachability.

Figure 4 presents the results of the loss on ignition (LOI) for the tested slag (S). LOI was determined by heating slag samples to the point of the solid mass in a muffle furnace at two temperatures: $60^{\circ} \mathrm{C}$ and $950{ }^{\circ} \mathrm{C}$ in the oxidizing atmosphere. In the analyzed case, it was found that LOI in $600{ }^{\circ} \mathrm{C}$ meets the permissible criteria for the disposal at the landfill of wastes other than hazardous and neutral (LOI $\leq 8 \%$ ). At the same time, loss on ignition for the slag was determined. The samples were tested by roasting in the temperature of $950^{\circ} \mathrm{C}$ through the extended time of a maximum of $1 \mathrm{~h}$. This parameter is essential for the mortar and concrete. The permissible limiting value of LOI for GBFS is $\leq 3 \%$. Significant loss on ignition in ash may result in deterioration of the workability of mortar and concrete. In the tested slag, LOI reached $5.56 \%$.

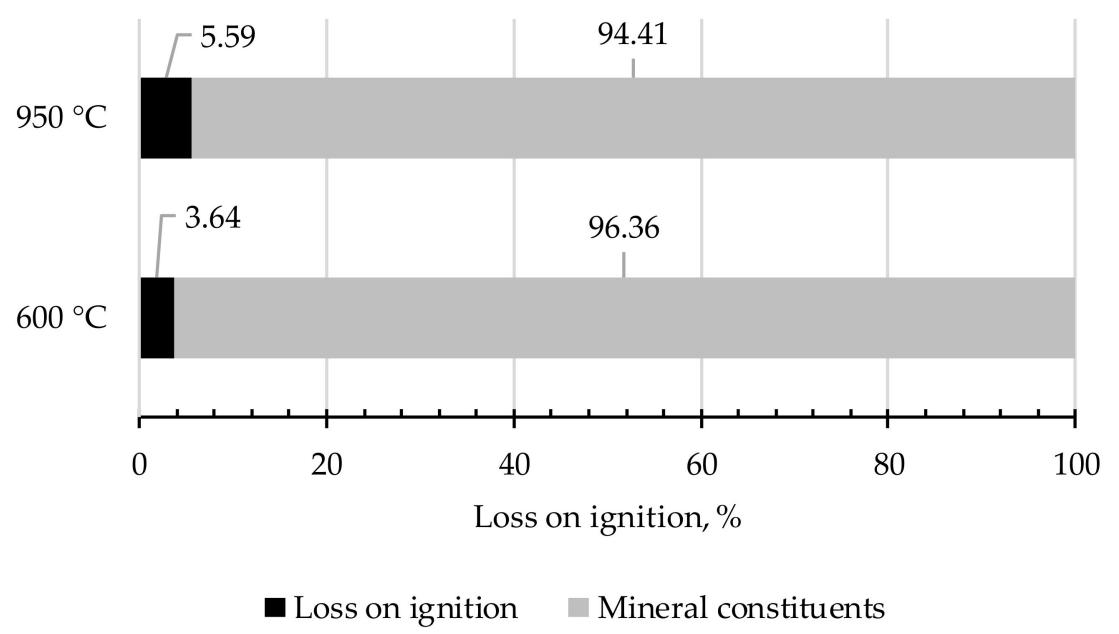

Figure 4. Loss on ignition (LOI) in the tested slag from MSWI.

Table 6 presents leachability of the selected contaminants from the slag, which may constitute a nuisance to the environment or adversely affect mechanical properties of the concrete mixture which would influence the concrete durability.

Secondary wastes from MSWI may pose a problem for the environment due to the high content of chloride salts and sulphates. Similar observations can be found in the publication [42]. Leachability of sulphates from the tested slag does not exceed a permissible value for the disposal at landfills for neutral wastes. However, the leachability level of sulphates is too high, slightly exceeding the acceptable value for the neutral wastes. The chemical requirements limit the content of chloride ions in the tested slag to $0.1 \%$. Moreover, the concentration of sulfur ions must be not higher than $2.5 \%$.

The aqueous extracts from the tested slag have been prepared to measure heavy metals concentration. These included: barium, zinc, copper, lead, cadmium, chrome, cobalt, iron, manganese and nickel. (Table 7). 
Table 6. Leachability of selected contaminants of tested slag, expressed in $\mathrm{mg} / \mathrm{kg}$ (with $\mathrm{pH}$ exception).

\begin{tabular}{ccccc}
\hline \multirow{2}{*}{ Properties } & Symbol & Slag-MSWI & \multicolumn{2}{c}{ Criteria for Landfills for [41] } \\
\cline { 4 - 5 } & & & Inert Waste & Non-Hazardous Waste \\
\hline pH & $\mathrm{pH}$ & 7.9 & - & minimum 6 \\
Total Carbon & $\mathrm{TC}$ & 118.00 & - & - \\
Total Organic Carbon & $\mathrm{TOC}$ & $\mathrm{BLQ}^{*}$ & 30000 & - \\
Total Inorganic Carbon & $\mathrm{TIC}$ & $\mathrm{BLQ}^{*}$ & - & - \\
Chloride & $\mathrm{Cl}^{-}$ & 780.00 & 800 & 20000 \\
Sulphate & $\mathrm{SO}_{4}{ }^{2-}$ & 1157.41 & 1000 & - \\
Phosphate trianion & $\mathrm{PO}_{4}^{-}$ & 100.00 & - & - \\
Potassium & $\mathrm{K}$ & 354.60 & - & - \\
Calcium & $\mathrm{Ca}$ & 878.40 & - & - \\
Lithium & $\mathrm{Li}$ & 2.70 & - & 60000 \\
Sodium & $\mathrm{Na}$ & 1104.00 & - & \\
The sum of chloride and & $\mathrm{TDS}$ & 1937.41 & 4000 & \\
sulphate & & & & - \\
\hline
\end{tabular}

BLQ*-Values below the limit of quantification.

Table 7. Content of heavy metals in water extracts from the slag tested, expressed in $\mathrm{mg} / \mathrm{kg}$.

\begin{tabular}{cccccc}
\hline \multirow{2}{*}{ Properties } & Symbol & CEM I & Slag-MSWI & \multicolumn{2}{c}{ Criteria for Landfills for [41] } \\
\cline { 5 - 6 } & & & Inert Waste & Non-Hazardous Waste \\
\hline Bar & $\mathrm{Ba}$ & $\mathrm{BLQ}^{*}$ & $\mathrm{BLQ}^{*}$ & 20 & 100 \\
Zinc & $\mathrm{Zn}$ & $\mathrm{BLQ}^{*}$ & 0.14 & 4 & 50 \\
Copper & $\mathrm{Cu}$ & 0.64 & $\mathrm{BLQ}^{*}$ & 2 & 50 \\
Lead & $\mathrm{Pb}$ & 0.15 & 0.60 & 0.5 & 10 \\
Cadmium & $\mathrm{Cd}$ & $\mathrm{BLQ}^{*}$ & 0.04 & 0.04 & 1 \\
Chrome & $\mathrm{Cr}$ & 50.1 & $\mathrm{BLQ}^{*}$ & 0.5 & - \\
Cobalt & $\mathrm{Co}$ & $\mathrm{BLQ}^{*}$ & $\mathrm{BLQ}^{*}$ & - & - \\
Iron & $\mathrm{Fe}$ & 1.80 & $\mathrm{BLQ}^{*}$ & - & - \\
Manganese & $\mathrm{Mn}$ & $\mathrm{BLQ}^{*}$ & $\mathrm{BLQ}^{*}$ & - & 10 \\
Nickel & $\mathrm{Ni}$ & 2.08 & 0.22 & 0.4 & 10 \\
\hline
\end{tabular}

BLQ*$^{*}$-Values below the limit of quantification.

The leachability level of heavy metals from the tested slag was very low. Only $\mathrm{Pb}$ level exceeded about $0.1 \mathrm{mg} / \mathrm{kg}$ the permissible value for the waste stored in the landfills for the neutral waste. The concentration of the other metals $(\mathrm{Zn}, \mathrm{Cd}, \mathrm{Ni})$ did not exceed the permissible values, and in many cases $(\mathrm{Ba}, \mathrm{Cu}, \mathrm{Cr}, \mathrm{Co}, \mathrm{Fe}, \mathrm{Mn})$ it was below the detection threshold.

Together with the physicochemical tests, mortar with 30\% addition of slag from MSWI was designed and produced. The mortars were maturing for 28 days in the laboratory conditions. After that, aqueous extracts were prepared. The leachability of contaminants from the mortar with the addition of the slag could be affected by the form of the mortar (monolith or crushed) which subsequently may influence the environmental nuisance.

In case of the monolith form, surface release process and diffusion determine to a large extent, the leachability level. In case of crushed mortar, the leachability level depends on the percolation process. The article presents tests for the leachability of contaminants for both forms of the mortars.

The MSWI slag should be tested to check its chemical composition before each use. Slag MSWI was evaluated over a period of two years. The slag composition fluctuates mainly in the scope of $\mathrm{CaO}$ and $\mathrm{Cr}$ due to the technology used in incineration plants in its valorisation. As a response to comparison requirements in the field of chemical fabric composition, granulated blast furnace slag GBFS can be adopted EN 15167-1: 2007 standard: "Ground granulated blast furnace slag for use in concrete, mortar and grout-Part 1: Definitions, specifications and compliance criteria" [16] presents the chemical (Table 1) that must be met so that, for example, ground granulated blast furnace slag can be used as 
a type II additive in the composition of concrete. Legal requirements for MSWI slag are necessary so that it can be used as an additive to concrete. We can only refer to requirements for blast furnace slag GBFS. It is necessary due to the heterogeneity of the slag from the MSWI installation, and the significant content of harmful components (unburned coal and sulfur compounds) are the main causes of low concrete resistance. If they refer to the requirements for blast furnace slag, it should meet the chemical requirements given in Table 8, and such should also be used for MSWI slag. The comparison of data from Tables 2-8 suggest that MSWI slag can be used in building practice because the analyzed standard requirements for slag as a replacement of cement material are mostly filled.

Table 8. The chemical requirements to be met by the slag GBFS and in comparison the research results of MSWI.

\begin{tabular}{cc}
\hline Ingredient Content & $\begin{array}{c}\text { The Standard Specification for Content (\% by Weight) in } \\
\text { Case of GBFS }\end{array}$ \\
\hline Magnesium oxide $(\mathrm{MgO})$ & $\leq 18.0$ \\
Sulfides $\left(\mathrm{S}^{2-}\right)$ & $\leq 2.0$ \\
Vitreous phase & $\geq 67.4$ \\
Sulfates $\left(\mathrm{SO}_{3}\right)$ & $\leq 2.5$ \\
Roasting loss & $\leq 3.0$ \\
Chlorides $\left(\mathrm{Cl}^{-}\right)$ & $\leq 1.0$ \\
Humidity & $\leq 1.0$ \\
\hline
\end{tabular}

Table 9 presents the properties of granulated blast furnace slag about the requirements of the EN 197-1 standard "Cement-Part 1. Composition, requirements and compliance criteria for common cement [18]." Table 2. Granulated blast furnace slag in the requirements of the EN 197-1 standard [18].

Table 9. The requirements of granulated blast furnace slag.

\begin{tabular}{cc}
\hline Requirements of EN 197-1 & Value \\
\hline content of the vitreous phase & $>95.0 \%$ \\
$\mathrm{CaO}+\mathrm{MgO}+\mathrm{SiO}_{2}$ & $\geq 2 / 3$ \\
$\mathrm{Ca}+\mathrm{MgO} / \mathrm{SiO}_{2}$ & $\geq 1.0 \%$ \\
\hline
\end{tabular}

GBSF slag is a cement component with latent hydraulic properties, and its activity depends on the alkalinity of the slag and thus on the $\mathrm{CaO}$ content. Too much $\mathrm{SiO}_{2}$ reduces the hydraulic activity of the slag. In case of tested MSWI the proportion between $\mathrm{CaO}, \mathrm{MgO}$ and $\mathrm{SiO}_{2}$ is adequate (Table 2).

\subsection{The Research Results of Properties of Fresh and Hardened Mortar with MSWI Slag}

\subsubsection{Properties of Fresh Mortar in the Aspect of Requirements of Slag as An Addition to Mortars}

Test results indicated that the analyzed cement paste (Figures 5 and 6 ) containing $30 \%$ of blast furnace slag maintains complete volume following the requirements of standard EN 197-1:2002 [18]. Le Chateliera's test (Figure 5) proves that the permissible $10 \mathrm{~mm}$ is not exceeded. Change of the volume of the mortar was $0.1 \%$.

Setting time of cement paste with $30 \%$ blast furnace slag (Figure 6) tested in automatic Vicatronic (Figure 7) was $325 \mathrm{~min}$ and ended after $555 \mathrm{~min}$. For comparison, the binding of Portland cement (CEM II/B-S 42\% N) starts after $240 \mathrm{~min}$ and ends after $300 \mathrm{~min}$. The cement paste time for binders with $30 \%$ of blast furnace slag (S) meets the requirements of standard EN 197-1 [18] concerning the minimum start of the binding time, which is $60 \mathrm{~min}$ for CEM I. 


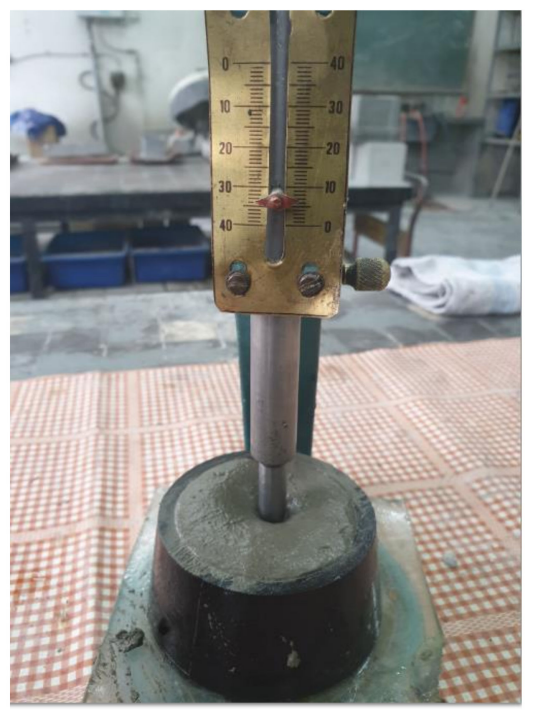

Figure 5. The view oement paste with MSWI slag under Chateliera's test (authors' photo).

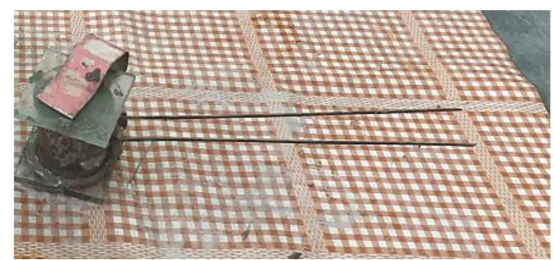

Figure 6. The view of normalized cement paste with MSWI slag in Vicat's apparatus (authors' photo).

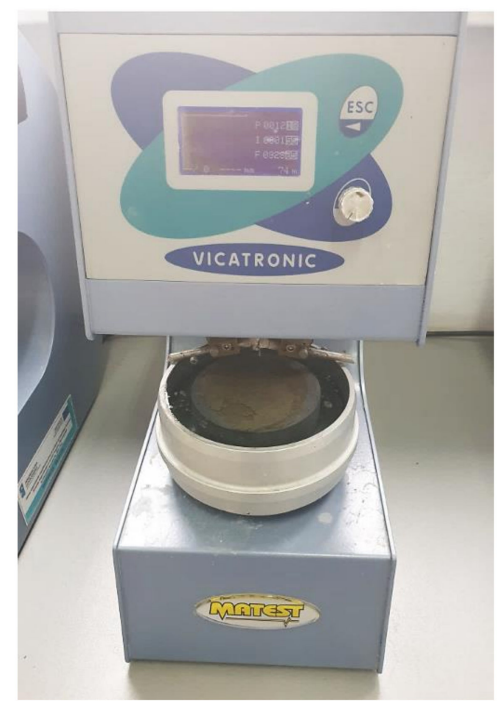

Figure 7. The view of cement paste with MSWI slag in automatic Vicastronic under measuring setting time (authors' photo). No volume change of cement paste was observed under measuring of setting time, which could affect the correct measurement.

Table 10 presents the properties of fresh mortars. The obtained results indicate that the fresh mortar with the 30\% addition of the slag-MSWI (S-MSWI) has similar properties than the mortar, which contained 30\% of GBSF. The flow diameter of the tested mortar mixtures (CEM I, CEM I $+30 \%$ S-MSWI, CEM I + 30\% GBFS) in time is on a similar level. 
Table 10. Properties of fresh mortar.

\begin{tabular}{ccccc}
\hline Properties & Unit & CEM I & CEM I + 30\% S-MSWI & CEM I + 30\% GBFS \\
\hline Flow value (initial) & $\mathrm{mm}$ & 150.0 & 160.0 & 160.0 \\
Flow value (after 60 $\mathrm{min})$ & $\mathrm{mm}$ & 140.0 & 150.0 & 150.0 \\
Air content & $\%$ & 2.5 & 3.1 & 2.9 \\
\hline
\end{tabular}

Figure 8 presents measurements of consistency of mortar with $30 \%$ addition of blast furnace slag. The research results indicate that the flow diameter of the mortar with GBSF and MSWI slags is similar, and is about $16 \mathrm{~cm}$. The time of keeping the consistency for $60 \mathrm{~min}$ is also similar.
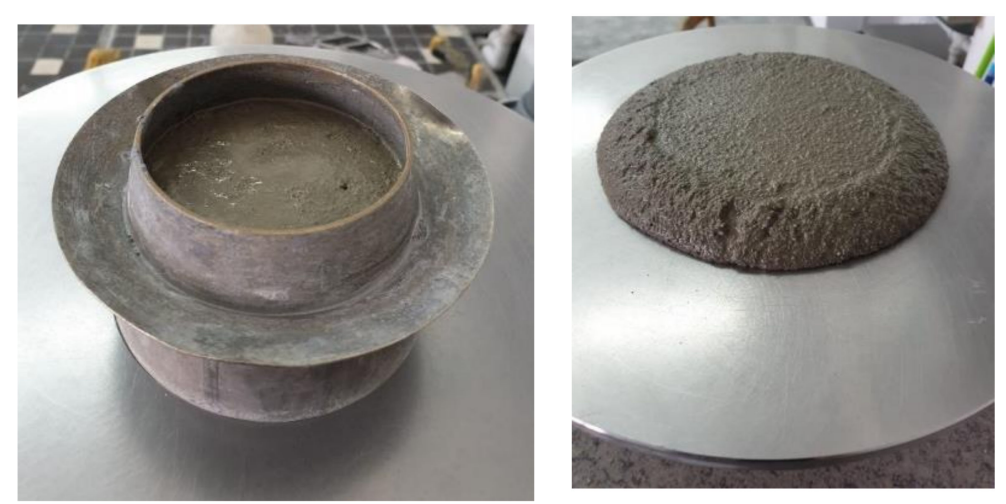

Figure 8. The flow of fresh mortar with the addition of $30 \%$ of MSWI slag after shaking 15 times (authors' photo).

Air content determined in the fresh mortar with MSWI and GBSF slag reached 2.5\% and 3.1\% respectively, which means that there is no significant influence of the type of slag on the air content of mortar.

Mentioned test results proved that tested cement pastes and mortars with $30 \%$ addition of MSWI slag meet the requirements of EN 196-3 [40].

\subsubsection{Properties of Hardened Mortar in the Aspect of Requirements of Slag as An Addition to Mortars}

Figure 9 showed that the mortar mortars with the $30 \%$ addition of slag did not swell, and preserved their original size. No performances or structure defects were observed.
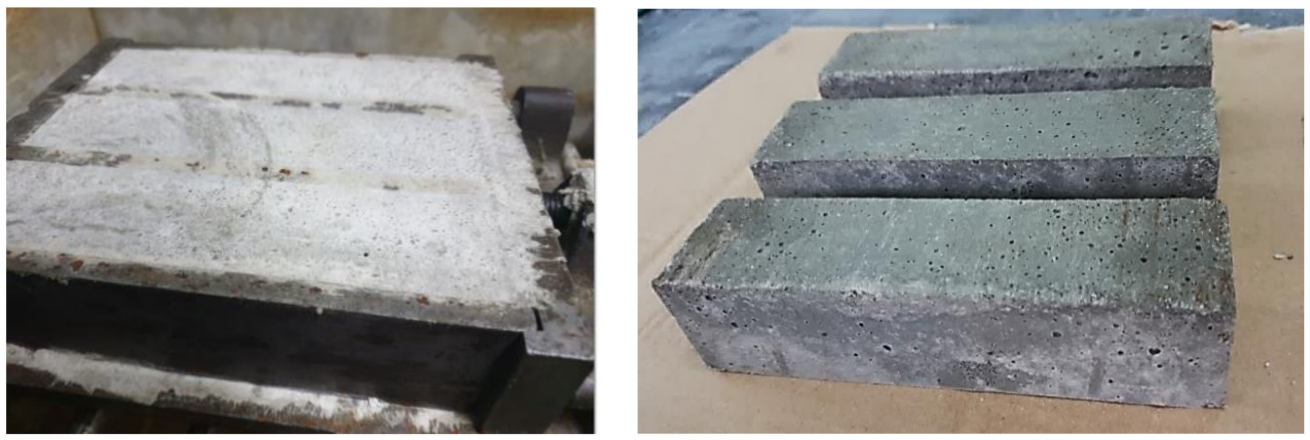

Figure 9. The view of mortars incorporating 30\% of slag from MSWI in form and samples were taken from after 1 day with $40 \times 40 \times 160 \mathrm{~mm}$ (authors' photo). No change of the mortar volume was observed.

Figures 10-12 present the results of compressive strength and tensile strength tests of mortars with the $30 \%$ addition of slag (S) from MSWI tested in automatic apparatus (Figure 8). For comparing the 
obtained results, the same tests were performed on the mortar with the $30 \%$ addition of the granulated blast furnace slag. Portland cement CEM I 42.5 R (CEM I) was used as a reference mortar.
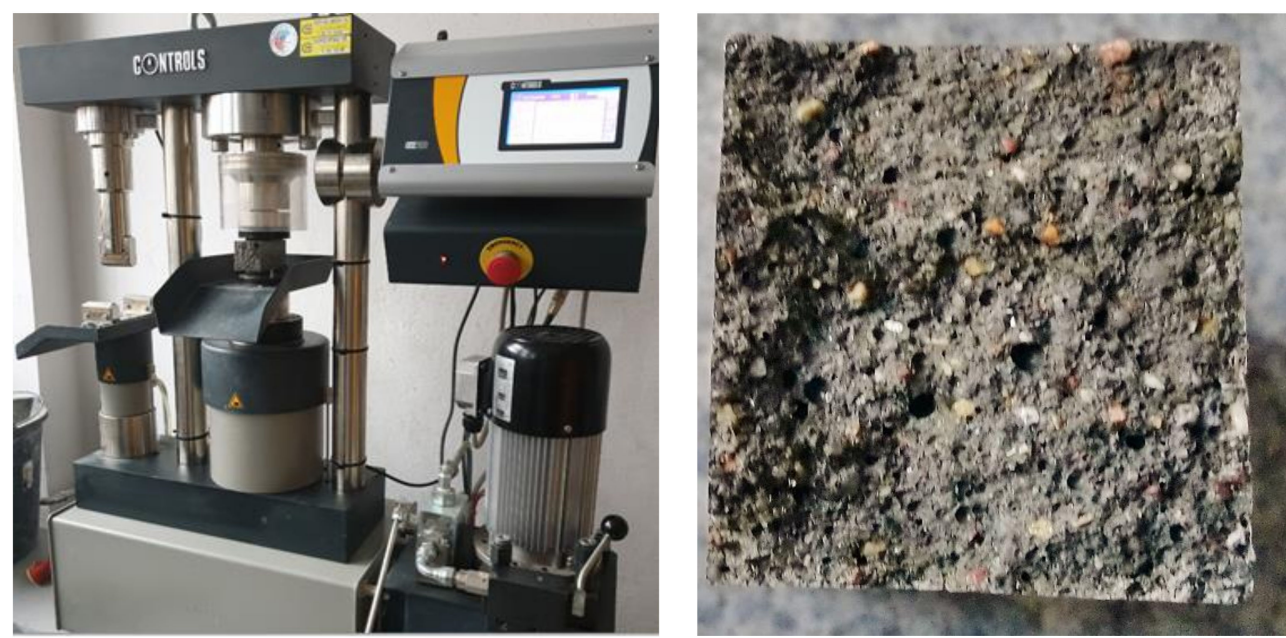

Figure 10. The view of compressive strength and tensile strength testing of mortars in the automatic apparatus and sample fracture structure (authors' photo).

$$
28 \text { days } \square 2 \text { days }
$$

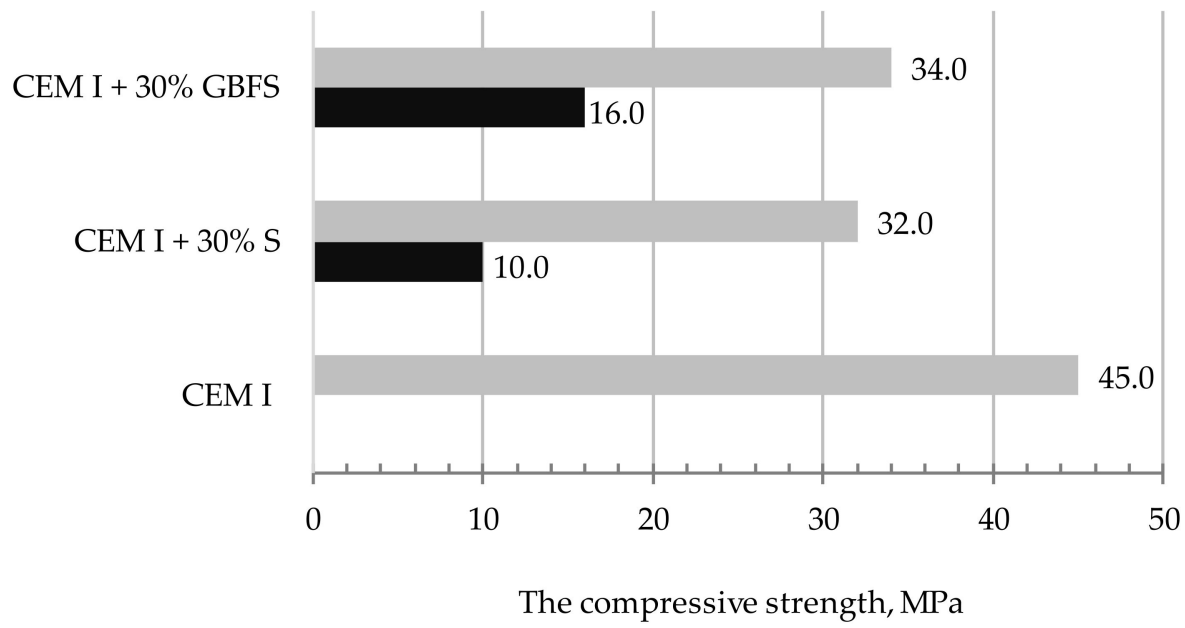

Figure 11. Results of compressive strength of mortars after 2 and 28 days of maturing. 


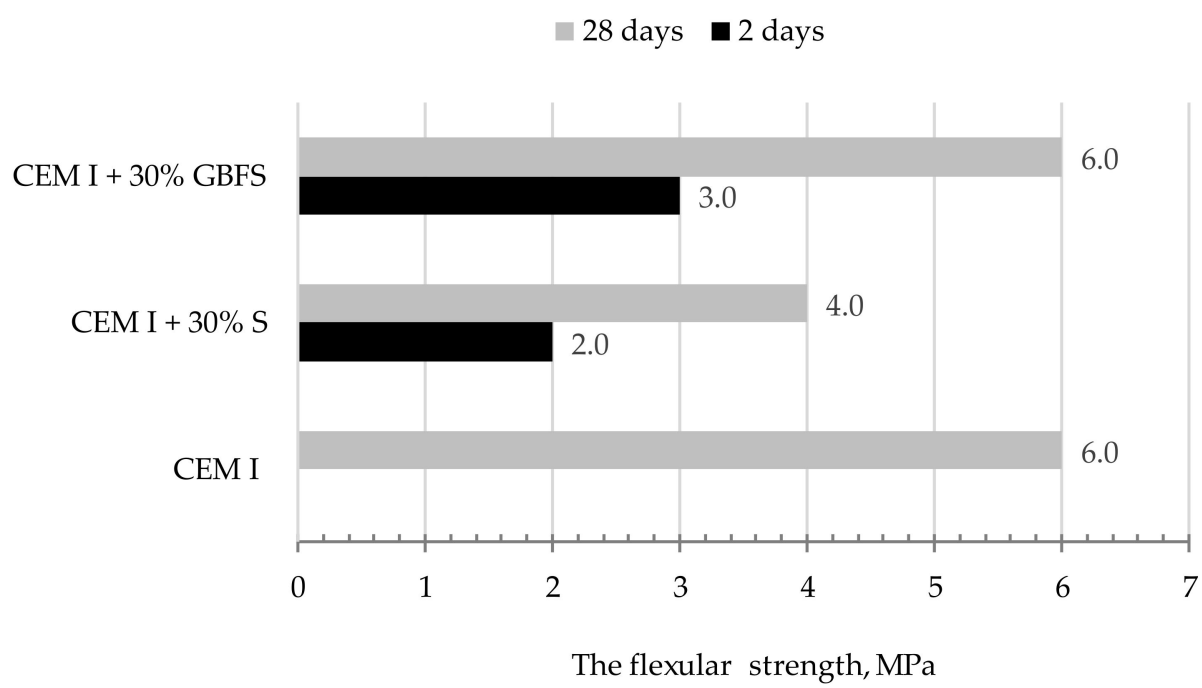

Figure 12. Results of bending tensile strength tests of mortars after 2 and 28 days of maturing.

Mortar with a binder containing 30\% of blast furnace MSWI slag showed lower compressive strength in the initial period of hardening (after two days) when compared to the mortar with $30 \%$ of GBFS (Figure 8). However, after 28 days of maturation, the compressive strength of the tested mortars did not differ much (2 $\mathrm{MPa})$. Based on the obtained results, it may be stated that the designed mortar matrixes may be used for similar engineering purposes.

The water absorption of the 28 days hardened mortar made with the $30 \%$ addition of the blast furnace slag reaches a level of $9 \%$. For comparison, the absorbability of the mash with GBSF slag is $7 \%$. In case of Portland cement (CEM I) water absorption falls in the range of $3 \%-8 \%$. It may be stated that the addition of slag does not significantly affect the water absorption of concrete. It is known that after 90 days, the absorbability of mortar with slag changes, reducing its value [12].

Analysis of the mechanical properties of mortars after 2 and 28 days of hardening indicates that slag (S) from MSWI plant is a component that fills microstructure of mortars without pozzolan properties, unlike GBFS. The reason for this is the lack of the vitreous phase in case of MSWI slag.

In case of MSWI slag particularly undesirable are reactions between cement and aluminum and zinc found in the wastes. Concrete may swell because of the salts such as sulfurs $\left(\mathrm{SO}_{4}\right)$, which can be found, for example, in the soil, in the direct contact with the concrete. It leads to a chemical reaction with aluminum contained in the cement generating an expansive substance. These phenomena may lead to inciting internal tensile forces and consequently to the occurrence of cracks, in case of excessive concrete resistance [43]. The reasons and the process of the above mentioned chemical reactions are described in details in the publications [44]. It is known that these reactions cause swelling and even cracking of concrete.

Furthermore, non-homogeneity of the slag from MSWI plant and significant content of harmful components (unburnt coal and sulfur compounds) are the main reasons for low resistance of the concrete and limit the way of its use. Depending on the composition, concrete strength reaches 2-10 MPa. Slag from MSWI plant shall not be used for the production of reinforced concretes and concretes exposed to permanent humidity over $75 \%$. When the amount of the substance mentioned above is high, mortar/concrete may tend to change volume (shrinkage, swelling) under the wet conditions. The reason is usually the content of unburnt coal. Water absorption of the hearth slag concrete, depending on the type of slag and composition of concrete, equals $15 \%-25 \%$. Frost resistance of hearth slag concrete is generally satisfactory, under the condition that the slag used does not contain a large amount of unburnt coal $(\mathrm{C}<5 \%)$, and the concrete resistance is not lower than $5 \mathrm{MPa}$ [12].

Concrete with the additive of slag from MSWI is used in the building industry almost exclusively for the production of various types of wall hollow bricks and less often for the construction of monolith 
walls at 1-2 floor in the individually constructed houses. Due to the unfavorable results of experiments, it is no longer used in the monolith wall, and only small wall elements are made of it.

To be suitable for use, the slag from MSWI plant in a responsible way, it needs to be seasoned and processed. Depending on the original composition and eventual destination, processing of slag may assume various forms (seasons, rinsing, washing, exposing to sodium hydroxide, removal of heavy metals, vitrification) to assure the expected quality of the concrete [8]. One of the most frequent problems will be the necessity to reduce aluminum and the amount of glass contained in the slag and control, among others the amount of unburnt coal, chloride, zinc and sulfur. Also, the possibility that the possible hazardous substances get through to the environment needs to be limited. [43,44].

Slags from MSWI require constant analysis, mainly referring to the chemical compositions. Based on the reports, a correct decision could be taken concerning their possible use, for example, for the production of concretes. A search for concrete with the addition of slag from MSWI plant that is environmentally friendly and that has excellent mechanical properties, suitable volume, and low leachability of contaminants is still ongoing [13,43-45].

\subsubsection{The Influence of Mortar with MSWI on Environment Research Results}

Table 11 presents the leachability of the selected contaminants from the 28 days hardened mortars. High $\mathrm{pH}$ value $(\mathrm{pH}>11)$ may indicate high mobilization of heavy metals, chloride salts and sulphates. The leachability of standard contaminants (chlorides, sulphates, TOC) does not exceed permissible levels for depositing wastes in the landfills for neutral wastes.

Table 11. Leachability of selected contaminants from mortar expressed in $\mathrm{mg} / \mathrm{kg}$ (with $\mathrm{pH}$ exception).

\begin{tabular}{cccccc}
\hline Properties & Symbol & CEM I & CEM I + 30\% S & \multicolumn{2}{c}{ Criteria for Landfills for [41] } \\
\cline { 5 - 6 } & & & & Inert Waste & $\begin{array}{c}\text { Non-Hazardous } \\
\text { Waste }\end{array}$ \\
\hline pH & $\mathrm{pH}$ & 8.9 & 11.1 & - & min. 6 \\
Total Carbon & $\mathrm{TC}$ & 89.20 & 89.20 & - & - \\
Total Organic Carbon & $\mathrm{TOC}$ & 55.80 & 55.80 & 30,000 & - \\
Total Inorganic Carbon & $\mathrm{TIC}$ & 33.40 & 33.40 & - & - \\
Chloride & $\mathrm{Cl}^{-}$ & 161.28 & 46.08 & 800 & 15,000 \\
Sulphate & $\mathrm{SO}_{4}^{2-}$ & 633.56 & 292.09 & 1000 & 20,000 \\
Phosphate trianion & $\mathrm{PO}_{4}^{-}$ & 20.33 & 24.00 & - & - \\
Potassium & $\mathrm{K}$ & 3.56 & 3.00 & - & - \\
Calcium & $\mathrm{Ca}$ & 4.97 & 2.54 & - & - \\
Lithium & $\mathrm{Li}$ & $\mathrm{BLQ}$ & $\mathrm{BLQ}$ & - & - \\
Sodium & $\mathrm{Na}$ & 3.08 & 2.08 & - & 60,000 \\
The sum of chlorides & $\mathrm{TDS}$ & 794.84 & 338.17 & 4000 & \\
and sulphates & & & & & - \\
\hline
\end{tabular}

BLQ*-Values below the limit of quantification.

The leachability of heavy metals from monolithic concrete forms after 28 days of their maturation is presented in Table 12.

The obtained levels of concentration of heavy metals in the aqueous extract were compared to the permissible values for wastes designated to the disposal at the landfills other than hazardous and neutral [41]. It needs to be noted that most of the values of heavy metals leachable from the mortar with the $30 \%$ addition of slag were definitely below the acceptable limit. The only value which exceeded the limit was $\mathrm{Ni}$ level. The concentration of these elements exceeded twice the requirements for the disposal at the neutral landfills.

Within the course of the conducted tests, also crushed mortar was exposed to the activity of the elusion liquid. Table 13 shows the concentration of the selected contaminants, which may be hazardous for the environment, in the aqueous extracts from the crushed mortar after 28 days of maturation. The increase in $\mathrm{pH}$ was noted $(\mathrm{pH}>12)$. Leachability of chloride salts in the crushed mortar increased 
more than 20 times in respect of the monolith mortar, exceeding the acceptable level for disposal at the landfill for the neutral wastes. Leachability of contaminants from the crushed mortars with the $30 \%$ addition of slag from MSWI did not exceed the permissible values for the wasted destined for disposal at landfills for wastes other than hazardous and neutral.

Table 12. Leachability of heavy metals from mortar (integral), expressed in $\mathrm{mg} / \mathrm{kg}$.

\begin{tabular}{|c|c|c|c|c|c|}
\hline \multirow{2}{*}{ Properties } & \multirow{2}{*}{ Symbol } & \multirow[b]{2}{*}{ CEM I } & \multirow{2}{*}{ CEM I $+30 \% \mathrm{~S}$} & \multicolumn{2}{|c|}{ Criteria for Landfills for [41] } \\
\hline & & & & Inert Waste & Non-Hazardous Waste \\
\hline Bar & $\mathrm{Ba}$ & $\mathrm{BLQ}^{*}$ & $\mathrm{BLQ}^{*}$ & 20 & 100 \\
\hline Zinc & $\mathrm{Zn}$ & $\mathrm{BLQ}^{*}$ & $\mathrm{BLQ}^{*}$ & 4 & 50 \\
\hline Copper & $\mathrm{Cu}$ & $\mathrm{BLQ}^{*}$ & $\mathrm{BLQ}^{*}$ & 2 & 50 \\
\hline Lead & $\mathrm{Pb}$ & 0.11 & 0.22 & 0.5 & 10 \\
\hline Cadmium & $\mathrm{Cd}$ & 0.01 & 0.04 & 0.04 & 1 \\
\hline Chrome & $\mathrm{Cr}$ & $\mathrm{BLQ}^{*}$ & $\mathrm{BLQ}^{*}$ & 0.5 & 10 \\
\hline Cobalt & $\mathrm{Co}$ & $\mathrm{BLQ}^{*}$ & $\mathrm{BLQ}^{*}$ & - & - \\
\hline Iron & $\mathrm{Fe}$ & $\mathrm{BLQ}^{*}$ & BLQ $^{*}$ & - & - \\
\hline Manganese & $\mathrm{Mn}$ & 0.04 & $\mathrm{BLQ}^{*}$ & - & - \\
\hline Nickel & $\mathrm{Ni}$ & $\mathrm{BLQ}^{*}$ & 0.84 & 0.4 & 10 \\
\hline
\end{tabular}

Table 13. Leachability of selected contaminants from crushed mortar, expressed in $\mathrm{mg} / \mathrm{kg}$ (with $\mathrm{pH}$ exception).

\begin{tabular}{cccccc}
\hline \multirow{2}{*}{ Properties } & \multirow{2}{*}{ Symbol } & CEM I & \multirow{2}{*}{$\begin{array}{c}\text { CEM I + 30\% } \\
\text { Slag-MSWI }\end{array}$} & \multicolumn{2}{c}{ Criteria for Landfills for [41] } \\
\cline { 5 - 6 } & & & Inert Waste & Non-Hazardous Waste \\
\hline TH & $\mathrm{pH}$ & 12.4 & 12.8 & - & min. 6 \\
Total Carbon & $\mathrm{TC}$ & 68.20 & 106.20 & - & - \\
Total Organic Carbon & $\mathrm{TOC}$ & 54.90 & 66.40 & 30,000 & - \\
Chorganic Carbon & $\mathrm{TIC}$ & 13.30 & 39.80 & - & - \\
Sulfides & $\mathrm{Cl}^{-}$ & 1198.08 & 944.64 & 800 & 15,000 \\
Phosphate trianion & $\mathrm{SO}_{4}^{2-}$ & 283.00 & 373.00 & 1000 & - \\
Potassium & $\mathrm{PO}_{4}^{-}$ & 25.33 & 12.33 & - & - \\
Calcium & $\mathrm{K}$ & 299.13 & 479.67 & - & - \\
Lithium & $\mathrm{Ca}$ & 590.43 & 1335.33 & - & - \\
Sodium & $\mathrm{Li}$ & 2.77 & 4.90 & - & - \\
The sum of chlorides & $\mathrm{Na}$ & 94.43 & 182.40 & - & 60,000 \\
and sulphates & $\mathrm{TDS}$ & 1200.91 & 948.37 & 4000 & \\
\hline
\end{tabular}

Table 14 presents the content of heavy metals in the aqueous extracts from crushed mortar after 28 days of maturation. It should be underlined that none of the concentration values of the heavy metals leachable from the crushed mortar made with $30 \%$ addition of slag exceeds the permissible value for the depositing at landfills other than hazardous and neutral. Only, similarly to the mortar, the content of $\mathrm{Ni}$ exceeds the limit. Fair value of this element exceeded the requirements for the neutral landfills more than four times. 
Table 14. Leachability of heavy metals from crushed mortar, expressed in $\mathrm{mg} / \mathrm{kg}$.

\begin{tabular}{cccccc}
\hline \multirow{2}{*}{ Properties } & Symbol & CEM I & CEM I + 30\% S & Inert Waste & Non-Hazardous Waste \\
\cline { 5 - 6 } & & & & 20 & 100 \\
Bar & $\mathrm{Ba}$ & $\mathrm{BLQ}^{*}$ & $\mathrm{BLQ}^{*}$ & 4 & 50 \\
Zinc & $\mathrm{Zn}$ & $\mathrm{BLQ}^{*}$ & $\mathrm{BLQ}^{*}$ & 2 & 50 \\
Copper & $\mathrm{Cu}$ & 0.07 & $\mathrm{BLQ}^{*}$ & 0.5 & 10 \\
Lead & $\mathrm{Pb}$ & 0.55 & $\mathrm{BLQ}^{*}$ & 0.04 & 1 \\
Cadmium & $\mathrm{Cd}$ & $\mathrm{BLQ}^{*}$ & $\mathrm{BLQ}^{*}$ & 0.5 & - \\
Chrome & $\mathrm{Cr}$ & $\mathrm{BLQ}^{*}$ & $\mathrm{BLQ}^{*}$ & - & - \\
Cobalt & $\mathrm{Co}$ & $\mathrm{BLQ}^{*}$ & $\mathrm{BLQ}^{*}$ & - & - \\
Iron & $\mathrm{Fe}$ & $\mathrm{BLQ}^{*}$ & $\mathrm{BLQ}^{*}$ & - & 10 \\
Manganese & $\mathrm{Mn}$ & $\mathrm{BLQ}^{*}$ & $\mathrm{BLQ}^{*}$ & 0.4 & - \\
Nickel & $\mathrm{Ni}$ & 0.13 & 1.87 &
\end{tabular}

BLQ*-Values below the limit of quantification.

\section{Conclusions}

The obtained results give a chance for environmentally friendly use of the slag in the construction industry. In many cases, the analyzed matter may constitute the best and the cheapest long term solution in the waste management economy, filling up the gap in the market in respect of the diminishing anthropogenic resources.

It is indispensable to legally determine the requirements for the slags from MSWI plants so that they could be used as an additive to the mortar and also in concrete. Mechanical tests showed that the MSWI slag might constitute the partial replacement of cement in mortar and concrete; the requirements of EN 196-3 [40] were fulfilled. Slag from MSWI plants assures similar aeration and consistency of the fresh mortar, also within time, similar to granulated blast furnace slag. Change of the volume of the standard slurry with $30 \%$ of the slag from MSWI equals $0.1 \%$, which meets the requirements for the cement with a large margin. Setting time of the cement paste with MSWI slag is 125 min longer than the cement with blast furnace slag. Mechanical parameters of mortars with MSWI slag after 2 and 28 days of maturation are lower than the mortar with the milled blast furnace slag, but cement meets the requirements for CEM II/B-S $32 \mathrm{~N}$ in this respect. Water absorption of mortars with MSWI slag is $3.0 \%$ higher than mortars with milled granulated blast furnace slag. However, this value may be limited by lowering the amount of water added to the cement in the mortar.

Conducted chemical tests proved that the use of MSWI slag in mortar would not cause any environmental nuisance. Furthermore, many physical and chemical properties of the slag from MSWI are similar to widely used in mortars crushed, granulated blast furnace slag. It must be remembered that the composition of MSWI slag depends on the structure of the municipal wastes directed to the incineration plant. That is why further tests concerning the variability of the chemical content of the slag over time need to be conducted.

Author Contributions: Conceptualization, M.C. and B.Ł.-P.; methodology, M.C. and B.Ł.-P.; validation, M.C. and B.Ł.-P.; formal analysis, M.C. and B.Ł.-P.; writing-original draft preparation, M.C. and B.Ł.-P. All authors have read and agreed to the published version of the manuscript.

Funding: Publishing supported by habilitation grant. The Silesian University of Technology, 08/030/RGH19/0070.

Conflicts of Interest: The authors declare no conflict of interest. The funders had no role in the design of the study; in the collection, analyses, or interpretation of data; in the writing of the manuscript, or in the decision to publish the results. 


\section{References}

1. Eurostat Statistics Explained. Available online: https://ec.europa.eu/eurostat/statistics-explained/index.php/ Main_Page (accessed on 19 February 2020).

2. Czop, M.; Łaźniewska-Piekarczyk, B. Evaluation of the leachability of contaminations of fly ash and bottom ash from the combustion of solid municipal waste before and after stabilization process. Sustainability 2019, 11, 5384. [CrossRef]

3. EUR-LEX. Directive (EU) 2018/851 of the European Parliament and of the Council of 30 May 2018 Amending Directive 2008/98/EC on Waste (Text with EEA Relevance). Available online: https://eur-lex.europa.eu/legalcontent/EN/TXT/?uri=uriserv:OJ.L_.2018.150.01.0109.01.ENG (accessed on 1 March 2020).

4. Czop, M.; Łaźniewska-Piekarczyk, B.; Bistuła, D.; Górniak, A.; Nowak, S.Z. Mechanical Properties of Cement Concrete Executed with the Dust from the Purification of Exhausts Following the Thermal Transformation of the Municipal Wastes. In Proceedings of the19th SGEM International Multidisciplinary Scientific GeoConference Green Buildings Technologies and Materials, Albena, Bulgaria, 28 June-7 July 2019.

5. Polski Rynek Węgla. Minerały Antropogeniczne a Gospodarka o Obiegu Zamkniętym. Available online: https://polskirynekwegla.pl/sites/default/files/elfinder/GOZ/mineraly-antropogeniczne.pdf (accessed on 21 February 2020).

6. European Commission. Best Available Techniques (BAT) Reference Document on Waste Incineration. Available online: https:/ec.europa.eu/jrc/en/publication/eur-scientific-and-technical-researchreports/best-available-techniques-bat-reference-document-waste-treatment-industrial-emissions (accessed on 21 February 2020).

7. Gomes, H.I.; Mayes, W.M.; Rogerson, M.; Stewart, D.I.; Burke, I.T. Alkaline residues and the environment: A review of impacts, management practices and opportunities. J. Clean. Prod. 2016, 112, 3571-3582. [CrossRef]

8. Robbie, M.A. Global $\mathrm{CO}_{2}$ emissions from cement production. Earth Syst. Sci. Data 2018, 10, 195.

9. Materials provided by an industrial partner-SUEZ Poland.

10. European Commission. Commission Decision of 18 December 2014 Amending Decision 2000/532/EC on the List of Waste Pursuant to Directive 2008/98/EC of the European Parliament and of the Council. Available online: https://eur-lex.europa.eu/legal-content/EN/TXT/PDF/?uri=CELEX:32014D0955 (accessed on 1 March 2020).

11. Sorlini, S.; Abba, A.; Collivignarelli, C. Recovery of MSWI and soil washing residues of concrete aggregates. Waste Manag. 2011, 31, 289-297. [CrossRef] [PubMed]

12. Neville, A.M. Properties of Concrete; Longman: Harlow, UK, 1995.

13. Ferraris, M.; Salvo, M.; Ventrella, A.; Buzzi, L.; Veglia, M. Use of vitrified MSWI bottom ashes for concrete production. Waste Manag. 2009, 29, 1041-1047. [CrossRef] [PubMed]

14. Müller, U.; Rübner, K. The microstructure of concrete made with municipal waste incinerator bottom ash as an aggregate component. Cem. Concr. Res. 2006, 36, 1434-1443. [CrossRef]

15. Pera, J.; Coutaz, L.; Ambroise, J.; Chababbet, M. Use of incinerator bottom ash in concrete. Cem. Concr. Res. 1997, 27, 1-5. [CrossRef]

16. BS EN 15167-1:2007: Ground Granulated Blast Furnace Slag for Use in Concrete, Mortar and Grout-Part 1: Definitions, Specifications and Conformity Criteria; British Standards Institution (BSI): London, UK, 2007.

17. EN 196-1-Methods of Testing Cement-Determination of Strength; European Committee for Standardization (CEN): Brussels, Belgium, 2016.

18. EN 197-1:2002, Cement. Czẹść 1: Skład, Wymagania i Kryteria Zgodności Dotyczące Cementów Powszechnego Użytku; Polish Committee for Standardization: Warsaw, Poland, 2002.

19. Król, A. Release of Heavy Metals From Mineral Composites Considering Environmental Impact; Opole University of Technology: Opole, Poland, 2012.

20. Król, A. The effect of different exposure conditions on the characteristics of the mineral matrices stabilizing hazardous waste. Ecol. Eng. 2016, 47, 143-150. [CrossRef]

21. PN Z-15008-02:1993 - Determination of Moisture Content; Polish Committee for Standardization: Warsaw, Poland, 1993.

22. EN 1097-3:2000—Determination of Bulk Density; European Committee for Standardization (CEN): Brussels, Belgium, 2000.

23. EN 196-6:2019-01-Cement Testing Methods_Part 6: Determination of Grinding Degree; European Committee for Standardization (CEN): Brussels, Belgium, 2019. 
24. EN 15935:2013-02—Determination of Loss on Ignition; European Committee for Standardization (CEN): Brussels, Belgium, 2013.

25. EN 196-2:2013-11—Determination of Loss on Ignition; European Committee for Standardization (CEN): Brussels, Belgium, 2013.

26. EN 15407:2011-Methods for the Determination of Carbon (C), Hydrogen (H) and Nitrogen (N) Content; European Committee for Standardization (CEN): Brussels, Belgium, 2011.

27. EN-Z-15011-3:2001-Municipal Solid Waste Compost-Determination of pH, Content of Organic Substance, Organic Carbon, Nitrogen, Phosphorus and Potassium; European Committee for Standardization (CEN): Brussels, Belgium, 2001.

28. EN-ISO 334:1997-Determination of Sulfur with the Eschka Method; International Standardisation Organisation (ISO): Geneva, Switzerland, 1997.

29. EN-ISO 587:2000-Determination of Chloride Using the Eschka Mixture; International Standardisation Organisation (ISO): Geneva, Switzerland, 2000.

30. EN-ISO 9964-3:1994-Determination of Sodium, Potassium, Calcium, Lithium and Bar by Flame Photometry; International Standardisation Organisation (ISO): Geneva, Switzerland, 1994.

31. EN ISO 15586:2005-Determination of Trace Elements by Atomic Absorption Spectrometry; International Standardisation Organisation (ISO): Geneva, Switzerland, 2005.

32. PN-EN 12457-2:2006 - Characterization of Waste-Leaching —Compliance Test for Leaching of Granular Waste Materials and Sludges-Part 2: One Stage Batch Test at a Liquid to Solid Ratio of $10 \mathrm{~L} / \mathrm{kg}$ for Materials with Particle Size Below $4 \mathrm{~mm}$ (Without or with Size Reduction); Polish Committee for Standardization: Warsaw, Poland, 2002.

33. EN ISO 10523:2012-Determination of pH; International Standardisation Organisation (ISO): Geneva, Switzerland, 2012.

34. EN 27888:1999-Determination of Electrical Conductivity; European Committee for Standardization (CEN): Brussels, Belgium, 1999.

35. EN 1484:1999_-Guidelines for the Determination of Total Organic Carbon (TOC); European Committee for Standardization (CEN): Brussels, Belgium, 1999.

36. PN-ISO 9297:1994-Determination of Chloride Ion Concentration by Titration (Mohr's Method); Polish Committee for Standardization: Warsaw, Poland, 1994.

37. PN-ISO 9280:2002-Determination of Sulphates (VI)_Gravimetric Method with Barium Chloride; Polish Committee for Standardization: Warsaw, Poland, 2002.

38. EN 1015-3-Methods of Test for Mortar for Masonry—Determination of Consistence of Fresh Mortar (by Flow Table); European Committee for Standardization (CEN): Brussels, Belgium, 2007.

39. EN 1015-7:1999-Methods of Test for Mortar for Masonry_Determination of Air Content of Fresh Mortar; European Committee for Standardization (CEN): Brussels, Belgium, 1999.

40. EN 196-3:2016-Methods of Testing Cement-Determination of Setting Times and Soundness; European Committee for Standardization (CEN): Brussels, Belgium, 2016.

41. The Council of the European Union. Council Decision of 19 December 2002 Establishing Criteria and Procedures for the Acceptance of Waste at Landfills Pursuant to Article 16 of and Annex II to Directive 1999/31/EC. Available online: https://eur-lex.europa.eu/LexUriServ/LexUriServ.do?uri=OJ:L:2003:011:0027: 0049:EN:PDF (accessed on 1 March 2020).

42. Cornelis, G.; Johnson, C.A.; Van Gerven, T.; Vandecasteele, C. Leaching mechanisms of oxyanionic metalloid and metal species in alkaline solid wastes: A review. Appl. Geochem. 2008, 23, 955-976. [CrossRef]

43. Bertolini, L.; Carsana, M.; Cassago, D.; Curzio, A.Q.; Collepardi, M. MSWI ashes as mineral additions in concrete. Cem. Concr. Res. 2004, 34, 1899-1906. [CrossRef]

44. Forteza, R.; Far, M.; Segul, C.; Cerda, V. Characterization of bottom ash in municipal solid waste incinerators for its use in road base. Waste Manag. 2004, 24, 899-909. [CrossRef] [PubMed]

45. Ginés, O.; Chimenos, J.M.; Vizcarro, A.; Formosa, J.; Rosell, J.R. Combined use of MSWI bottom ash and fly ash as aggregate in concrete formulation: Enviromental and mechanical considerations. J. Hazard. Mater. 2009, 169, 643-650. [CrossRef] [PubMed] 